\title{
Identification of a scavenger receptor in rat luteal cells which recognizes chemically modified lipoproteins and mediates the uptake of cholesterol for steroidogenesis
}

\author{
Zhouji Chen and K.M.J. Menon \\ Departments of Obstetrics and Gynecology and Biological Chemistry, University of Michigan Medical School, Ann Arbor, MI (USA)
}

(Received 5 February 1993)

Key words: Acetyl-LDL; LDL; Scavenger receptor; Steroidogenesis; (Rat luteal cell)

\begin{abstract}
The presence of the acetyl low density lipoprotein (acetyl-LDL), or scavenger receptor, which binds modified forms of LDL, was examined in rat luteal cells. Acetyl-LDL supported progesterone production by dispersed rat luteal cells at least equal to that of the native LDL under basal conditions and in the presence of human chorionic gonadotropin (hCG). The acetyl-LDL-supported progesterone production was stimulated by hCG and dibutyryl cAMP in a concentration-dependent manner. Studies on acetyl-LDL binding to ovarian plasma membranes revealed a single class of binding sites with high affinity. The binding is specific in that unlabeled acetyl-LDL and fucoidin, a known competitor for binding to scavenger receptor, were effective competitors, while native LDL was not. Furthermore, degradation of ${ }^{125} \mathrm{I}$-acetyl-LDL by cultured luteal cells was inhibited by unlabeled acetyl-LDL and fucoidin but not native LDL. The experiments on cross-competition between acetyl-LDL and tetranitromethane-modified high density lipoprotein (TNM-HDL) indicated that TNM-HDL is also recognized as a ligand by this receptor. In addition, in vivo pretreatment of rats with hCG resulted in induction of acetyl-LDL binding activity of ovarian plasma membranes in a time-dependent manner when compared to saline injected controls. The increase in binding activity was due to an increase in the number of binding sites rather than to a change in the binding affinity. In conclusion, this study demonstrates that, in addition to receptor-mediated LDL and HDL pathways, rat luteal cells possess a scavenger receptor pathway, which recognizes TNM-HDL as well as acetyl-LDL. This receptor may play an important role in the uptake and utilization of modified lipoprotein-associated cholesterol by luteal cells.
\end{abstract}

\section{Introduction}

Plasma lipoprotein-derived cholesterol is the major source of substrate for steroidogenesis by luteal cells $[1,2]$. Receptor-mediated uptake and utilization of low density lipoprotein (LDL)- and high density lipoprotein (HDL)-derived cholesterol for progestin production have been well characterized in rat ovarian cells [3-5]. It has also been shown that nitrated HDL, in which tyrosine residues are modified with tetranitromethane, does not bind to the HDL receptor [6,7]. However, like native HDL, nitrated HDL also supports steroidogenesis by rat ovarian cells [7]. One interpretation of this

Correspondence to: K.M.J. Menon, Department of Obstetrics and Gynecology, University of Michigan Medical School, 1500 E. Medical Center Drive, Endocrine Laboratory, Ann Arbor, MI 48109-0278, USA.

Abbreviations: LDL, low-density lipoprotein; HDL, high-density lipoprotein; apo, apolipoprotein; PMSG, pregnant mare's serum gonadotropin; hCG, human chorionic gonadotropin; SDS-PAGE, sodium dodecyl sulfate-polyacrylamide gel electrophoresis. was the suggestion that HDL receptor may not be required for the uptake of HDL-derived cholesterol by steroidogenic cells $[7,8]$. However, the mechanism(s) for the delivery of nitrated HDL-carried cholesterol in luteal cells is not yet known. Recently, it has been shown that nitrated HDL is recognized by a scavenger receptor of rat liver endothelial cells [9]. This raises a possibility that the delivery of nitrated HDL-carried cholesterol might also be mediated by a scavenger receptor in ovarian cells.

Scavenger receptor is a family of cell-surface receptors specific for chemically modified proteins such as the chemically modified LDL, acetylated LDL $[10,11]$. Modification of the lysine residues of apoprotein B of LDL by acetylation abolishes its binding to the LDL receptor but it becomes a ligand for the scavenger receptor [10]. After its binding to the scavenger receptor, the modified LDL is internalized and then degraded in lysosomes, followed by the release of cholesterol in the cytoplasm [11]. This receptor-mediated endocytotic process is similar to the LDL receptor pathway. However, in contrast to the LDL receptor, 
expression of the scavenger receptor is not down-regulated by an increase in intracellular cholesterol level [11]. Scavenger receptor was originally found in peritoneal macrophages, Kupffer cells and cultured human monocytes [10], and was subsequently shown to be expressed by endothelial cells [12]. A recent study has shown that rabbit fibroblasts and smooth muscle cells also express scavenger receptor [13]. However, the expression of scavenger receptor has not been demonstrated in the steroidogenic cell, which utilizes plasma lipoprotein cholesterol as a steroidogenic substrate.

To determine whether rat luteal cells express scavenger receptor and whether nitrated HDL binds to this receptor, we assessed the ability of acetyl-LDL to support progesterone production by rat luteal cells and characterized the binding of acetyl-LDL to luteinized rat ovarian plasma membranes. This study presents evidence that rat luteal cells possess a scavenger receptor pathway which delivers acetyl-LDL cholesterol for progesterone synthesis and that nitrated HDL is recognized by this receptor.

\section{Experimental procedures}

\section{Materials}

Pregnant mare serum gonadotropin (PMSG) was obtained from Calbiochem (La Jolla, CA). HCG was kindly donated by National Hormone Distributing Program and the University of Maryland School of Medicine. Tetranitromethane (TNM), dibutyryl cyclic AMP (Bt ${ }_{2}$-cAMP) and fucoidin were products of Sigma (St. Louis, MO). Minimal essential medium (MEM)410 , McCoys $5 \mathrm{~A}$ medium and fetal bovine serum were purchased from GIBCO (Grand Island, NY). Human plasma, collected from healthy donors, was obtained from the Blood Bank, University of Michigan Hospitals, Ann Arbor, MI. Sodium [ ${ }^{125}$ I]iodide (carrier-free in aqueous solution, $\mathrm{pH} 8-10$ ) was purchased from New England Nuclear-Du Pont (Boston, MA). All other chemicals used were of analytical grade obtained from commercial sources.

\section{Methods}

Lipoprotein isolation, modification and labelling. $\mathrm{Hu}-$ man LDL ( $d$ 1.019-1.063 g/ml) and HDL ( $d$ 1.063$1.215 \mathrm{~g} / \mathrm{ml}$ ) were isolated from normal human plasma by sequential ultracentrifugation after adjusting the density with $\mathrm{KBr}$ as described previously $[14,4]$. The isolated HDL was further processed by heparin-agarose affinity chromatography to remove apolipoprotein $\mathrm{E}$ [15]. The absence of apolipoprotein $\mathrm{E}$ in the purified HDL was examined by SDS-PAGE [16]. Lipoproteins were extensively dialyzed against $0.15 \mathrm{M} \mathrm{NaCl}$ containing $0.3 \mathrm{mM}$ EDTA ( $\mathrm{pH} \mathrm{7.4),} \mathrm{sterilized} \mathrm{by} \mathrm{filtration}$ through a $0.22 \mu \mathrm{m}$ Millipore filter and then stored at $4^{\circ} \mathrm{C}$ until used.
Acetyl-LDL (AcLDL) was prepared by acetylation of LDL with acetic anhydride according to the procedure of Basu et al. [17]. Nitrated HDL (TNM-HDL) was prepared by nitration with TNM using a 10 -fold molar excess of TNM relative to tyrosine residues of apo AI of HDL as described by Nestler et al. [7]. The effects of these chemical modifications on the physicochemical characteristics of LDL and HDL were examined by SDS-PAGE [16] and by agarose gel electrophoresis [18] of the native and modified lipoproteins.

The lipoproteins were radiolabeled with ${ }^{125} \mathrm{I}$ by a modified McFarlane procedure [19] as described previously [4]. The labelling of acetyl-LDL was carried out after acetylation, whereas the labeled TNM-HDL was prepared by labelling the native HDL before nitration. The specific activities of ${ }^{125} \mathrm{I}$-acetyl-LDL and ${ }^{125} \mathrm{I}$ TNM-HDL were $140-320$ and $700-900 \mathrm{cpm} / \mathrm{ng}$ protein, respectively.

Animals and treatment. Immature 21-day-old Sprague-Dawley female rats were made pseudopregnant by injection with 50 IU PMSG, followed $56 \mathrm{~h}$ later by a single injection of $25 \mathrm{IU}$ of hCG [20]. Five days after hCG injection, the rats were killed by $\mathrm{CO}_{2}$ asphyxiation to obtain highly luteinized ovaries.

Preparation and incubation of dispersed luteal cells for progesterone synthesis. The ovaries from the pseudopregnant rats, upon removal, were immediately minced and the cells dispersed with collagenase as described previously [21]. Following dispersion, the cells were washed twice with MEM-410/0.5\% bovine serum albumin (BSA) and then resuspended at a concentration of approx. $2 \cdot 10^{7}$ cells $/ \mathrm{ml}$. The viability of the cells ranged from 80 to $90 \%$ as examined by Trypan blue exclusion test. Aliquots of cells (approx. $2 \cdot 10^{6}$ cells in $0.1 \mathrm{ml}$ ) were added to $75 \times 12 \mathrm{~mm}$ tubes containing $0.3 \mathrm{ml}$ MEM-410/0.5\% BSA and where required, appropriate concentrations of acetyl-LDL, LDL, hCG or cAMP as specified in the figure legends. The cells were then incubated at $37^{\circ} \mathrm{C}$ for $3 \mathrm{~h}$ in a shaking water bath in the presence of $\mathrm{O}_{2} / \mathrm{CO}_{2}(95: 5, \mathrm{v} / \mathrm{v})$. At the end of incubation, the sample tubes were centrifuged at $3000 \times g$ at $0^{\circ} \mathrm{C}$ for $10 \mathrm{~min}$ to separate the medium from cell pellets. The medium was then removed and saved for progesterone RIA [1] and the cell pellets were assayed for DNA content by the method of Burton [22].

Luteal cell culture and cellular degradation of ${ }^{125} \mathrm{I}$ acetyl-LDL. Cells were isolated from luteinized ovaries of pseudopregnant rats as described previously [23]. The final density of luteal cells in the suspension was about $2 \cdot 10^{7}$ cells $/ \mathrm{ml}$. The viability of cells were 80 $90 \%$ based on Trypan blue exclusion test. The cells were plated onto 24-well culture dishes (Falcon Primaria; Falcon Plastics, Los Angeles, CA) in $0.5 \mathrm{ml}$ McCoys 5A medium containing $10 \%$ fetal bovine serum. After overnight incubation at $37^{\circ} \mathrm{C}$ under a 
water-saturated atmosphere of $95 \%$ air $/ 5 \% \mathrm{O}_{2}$, the cells were washed three times with serum-free McCoys medium and then incubated at $37^{\circ} \mathrm{C}$ for $6 \mathrm{~h}$ in $0.5 \mathrm{ml}$ serum-free McCoys medium containing $3 \mu \mathrm{g}{ }^{125} \mathrm{I}$ acetyl-LDL and varied amounts of unlabeled acetylLDL, LDL, or fucoidin. At the termination of incubation, the culture dishes were placed on ice and the medium was removed and brought to a final concentration of $10 \%$ trichloroacetic acid. The trichloroacetic acid-soluble lipoprotein degradation products in the medium were quantitated as described by Bierman et al. [24]. Nonspecific degradation was determined in the presence of 200 -fold excess of unlabeled acetyl-LDL and subtracted from total degradation to obtain specific degradation.

Isolation of luteinized ovarian plasma membranes. Fresh, highly luteinized rat ovaries were weighed and homogenized at $4^{\circ} \mathrm{C}$ in a glass homogenizer fitted with a Teflon pestle. Partially purified plasma membranes were prepared by a differential centrifugation method of Powell et al. [25] and as described previously by our laboratory [26]. The relative purification of plasma membranes was ascertained by assaying the activities of the plasma membrane marker enzyme 5'-nucleotidase (EC 3.1.3.5) [27] and the mitochondrial marker enzyme succinate-2-( $p$-indophenyl)-3-( $p$-nitrophenyl)5-phenyltetrazolium reductase (EC 1.3.99.1) [27]. The membrane preparation was enriched 4-fold on the basis of the plasma membrane marker enzyme 5'-nucleotidase, with negligible mitochondrial contamination.

Lipoprotein binding assays. Aliquots of membranes ( $250 \mu \mathrm{g}$ protein) were incubated with constant amounts of ${ }^{125} \mathrm{I}$-acetyl-LDL $(5 \mu \mathrm{g} / \mathrm{ml}, 150-300 \mathrm{cpm} / \mathrm{ng}$ protein) or ${ }^{125} \mathrm{I}-\mathrm{TNM}-\mathrm{HDL}(4 \mu \mathrm{g} / \mathrm{ml}, 700-900 \mathrm{cpm} / \mathrm{ng}$ protein) and increasing amounts of unlabeled competitors (as specified in the figure legends) or a 200 -fold excess of unlabeled acetyl-LDL or TNM- HDL (for nonspecific binding) in a final volume of $0.5 \mathrm{ml}$ binding assay buffer (20 mM Tris- $\mathrm{HCl}, \mathrm{pH} 7.4,150 \mathrm{mM} \mathrm{NaCl}$, $1 \% \mathrm{BSA}$ ). The reaction tubes were then incubated at $37^{\circ} \mathrm{C}$ for $90 \mathrm{~min}$ and then unbound ligands were separated from the receptor-bound fractions by filtration through Millipore cellulose acetate filters $(0.45 \mu \mathrm{m}$; Millipore, Bedford, MA) followed by washing the filters with $3 \mathrm{ml}$ ice-cold binding assay buffer four times. The radioactivity in the filters was then quantitated using a gamma counter (Tracor analytic, Elk Grove Village, IL). Unless otherwise specified, binding assays were done in triplicates. Binding parameters were determined by nonlinear curve fitting using the Ligand Computer Program (Bio-Soft, Milltown, NJ).

Miscellaneous procedures. Protein content of samples was determined with Pierce BCA Protein Assay Reagent (Pierce, Rockford, IL) using BSA as a standard. Cholesterol and cholesterol esters in LDL and acetyl-LDL were assayed by the method of Deacon and Dawson [28]. The data represent the means \pm S.E. of the number of determinations and were analyzed by analysis of variance and multiple $t$-tests to compare differences among treatments.

\section{Results}

Physico-chemical characteristics of acetyl-LDL and TNM-HDL

Acetylation of LDL with acetic anhydride had no effect on cholesterol content; the ratios of protein to cholesterol and that of free cholesterol to esterified cholesterol in native LDL were similar to those of acetyl-LDL $(1: 1.50$ and $1: 5.95$ vs. $1: 1.53$ and $1: 5.80$, for native LDL and acetyl-LDL, respectively). No significant change in the apparent molecular weight of apo $B$ of LDL resulting from acetylation was observed (Fig. 1 panel A). Conversely, all protein bands corresponding to the apoliproteins of the native HDL were absent in TNM-HDL and a broad new band appeared at the high molecular weight region of the gel, indicating extensive cross-linking of apoliproteins (Fig. 1 panel A) as reported previously [6,7]. As assessed by agarose gel electrophoresis at $\mathrm{pH} 8.6$ (Fig. 1 panel B), acetylLDL had a significantly enhanced negative charge relative to native LDL, whereas TNM-HDL showed only a slightly enhanced negative charge as compared to native HDL. This increase in negative charges in acetylLDL and TNM-HDL has been reported previously $[6,7,17]$.

Stimulation of luteal cell progesterone production by acetyl- $L D L$

Previous studies have shown that LDL delivers its cholesterol to luteal cells for progesterone production through the LDL receptor pathway [3,23]. It is also known that acetyl-LDL can not deliver its sterols to cells such as human fibroblasts, which do not possess a scavenger receptor pathway [10]. Therefore, to examine the presence of a functional scavenger receptor in luteal cells, we initially compared the abilities of native LDL and acetyl-LDL to support progesterone production by dispersed rat luteal cells. As shown in Fig. 2, acetyl-LDL stimulated progesterone production in a concentration-dependent manner similar to that of native LDL both under basal and under hCG-stimulated conditions. The stimulation reached a significant level ( $72 \%$ and $47 \%$ increase over the control, under basal and hCG-stimulated conditions, respectively; $P<0.05$ ) when the acetyl-LDL was added at a concentration of $50 \mu \mathrm{g} / \mathrm{ml}$. A maximal stimulation of 1.4-fold increase in progesterone production $(P<0.01)$ was observed in the presence of acetyl-LDL at concentrations of 200 $400 \mu \mathrm{g} / \mathrm{ml}$ (Fig. 2).

The acetyl-LDL-supported progesterone production was stimulated by hCG and cAMP in a dose-depen- 
A

Mr $\times 10^{3}$ STD1 STD2 LDL ACLDL HDL TMM-HDL

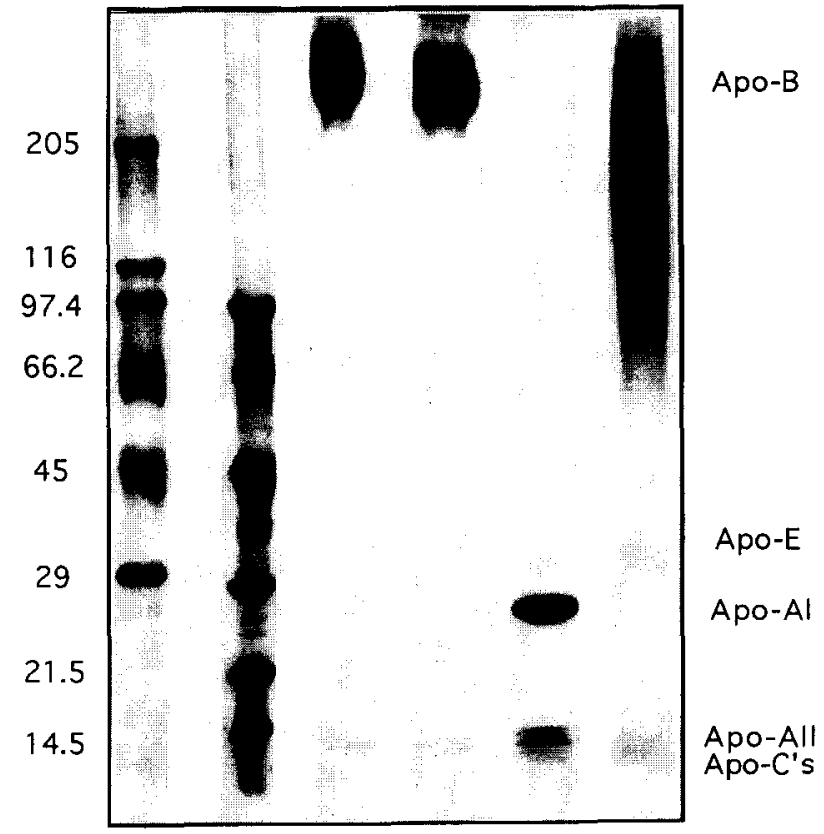

B

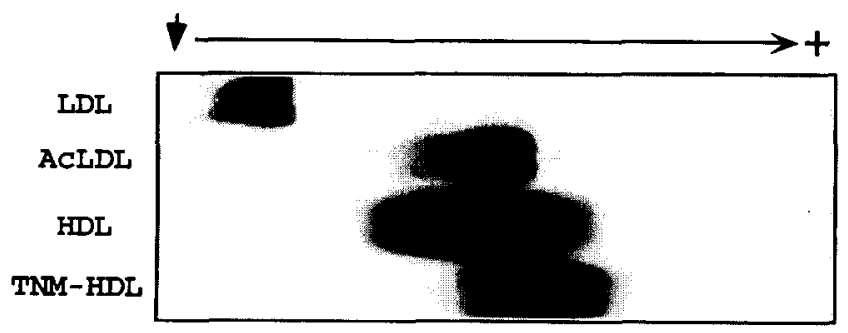

Fig. 1. SDS-PAGE electrophoresis (panel A) and agarose gel electrophoresis (panel B) of lipoproteins before modification (LDL, HDL) and after modification (AcLDL, TNM-HDL). $20 \mu \mathrm{g}$ of each lipoprotein were electrophoresed on a SDS-PAGE gradient gel (4-20\%) or agarose gel. The gels were visualized by staining with Coomasie brilliant blue. The arrow head and the arrow in agarose gel (panel B) show the origin and the direction, respectively.

dent manner (Fig. 3). Acetyl-LDL showed a 5- and 7-fold increase in progesterone production in response to $\mathrm{hCG}$ and $\mathrm{Bt}_{2}$-cAMP, respectively. As expected, the LDL-supported progesterone production was also stimulated by $\mathrm{hCG}$ and $\mathrm{Bt}_{2}$-cAMP in a similar dose-response manner (Fig. 3). A time-course study demonstrated that the stimulatory effects on luteal cell progesterone production by acetyl-LDL as well as LDL and hCG were time-dependent (Fig. 4). Taken together, these data demonstrate the ability of acetylLDL to deliver its cholesterol to luteal cells for steroidogenesis in an unequivocal manner. The utilization of cholesterol from acetyl-LDL for progesterone production suggests that a scavenger receptor pathway might be operational in rat luteal cells.
Binding of acetyl-LDL to rat luteinized ovarian plasma membranes

To further examine the possible existence of scavenger receptor in luteal cells, we determined the binding of ${ }^{125}$ I-acetyl-LDL to plasma membrane preparations from luteinized rat ovaries. As shown in Fig. 5, the binding of ${ }^{125} \mathrm{I}$-acetyl-LDL to ovarian plasma membranes was saturable. Scatchard plot [29] of the binding data showed a linear plot with an equilibrium dissociation constant $\left(K_{\mathrm{d}}\right)$ of $23 \mathrm{mg}$ acetyl-LDL/ml and the $B_{\max }, 5.85 \mathrm{mg}$ acetyl-LDL/mg membrane protein, reflecting a single class of high-affinity acetyl-LDL binding sites. The binding of acetyl-LDL was not displaced by native $\mathrm{LDL}$, whereas unlabeled acetyl-LDL and fucoidin, a known competitor for binding to the scavenger receptor, competitively inhibited this binding by 90\% (Fig. 6). These results demonstrate the presence of a distinct scavenger receptor in ovarian plasma membranes which is different from the LDL receptor.

It is known that acetyl-LDL will undergo internalization after it binds to the scavenger receptor on the cell [10]. Therefore, the cellular degradation of ${ }^{125} \mathrm{I}$ acetyl-LDL by cultured luteal cells was determined in order to delineate the mechanisms of cholesterol delivery in luteal cells. As shown in Fig. 7, cellular degradation of ${ }^{125}$ I-acetyl-LDL to trichloroacetic acid-soluble particles occurred in luteal cells. Native LDL was unable to inhibit the degradation of ${ }^{125}$ I-acetyl-LDL, suggesting that acetyl-LDL does not interact with LDL

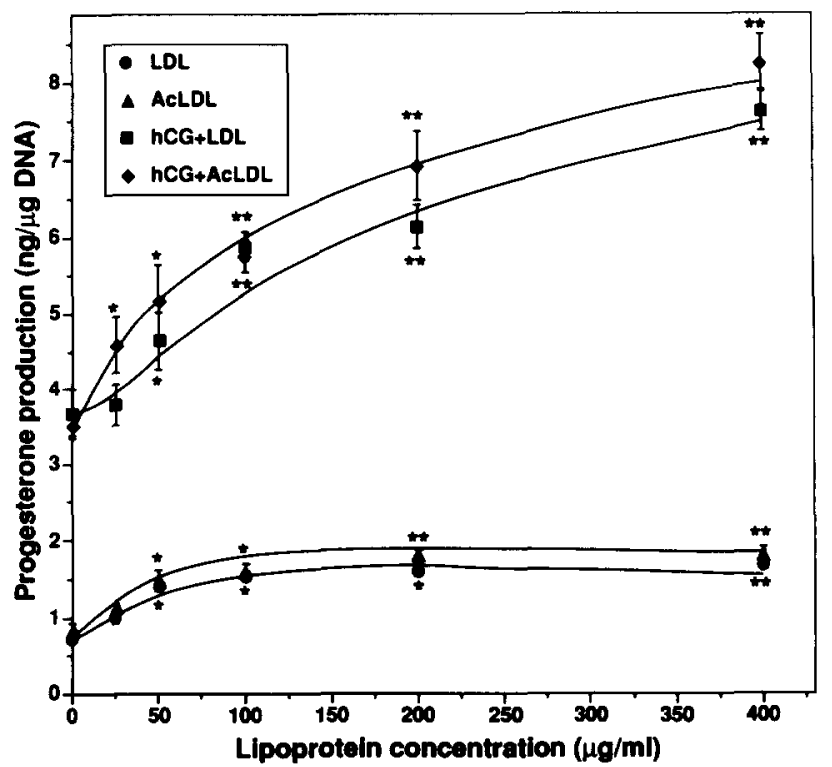

Fig. 2. Effects of acetyl-LDL (AcLDL) and native LDL (LDL) on progesterone secretion by dispersed rat luteal cells. Rat luteal cells (approx. $2 \cdot 10^{6}$ ) were incubated with the indicated concentrations of LDL or AcLDL alone or in the presence of hCG $(100 \mathrm{ng} / \mathrm{ml})$ at $37^{\circ} \mathrm{C}$ for $3 \mathrm{~h}$. Progesterone was determined by radio-immunoassay. Values presented are the means $\pm S$.E. of triplicate incubations. ${ }^{*} P<0.05 ;{ }^{*} P<0.01$, significant differences when compared to controls. 

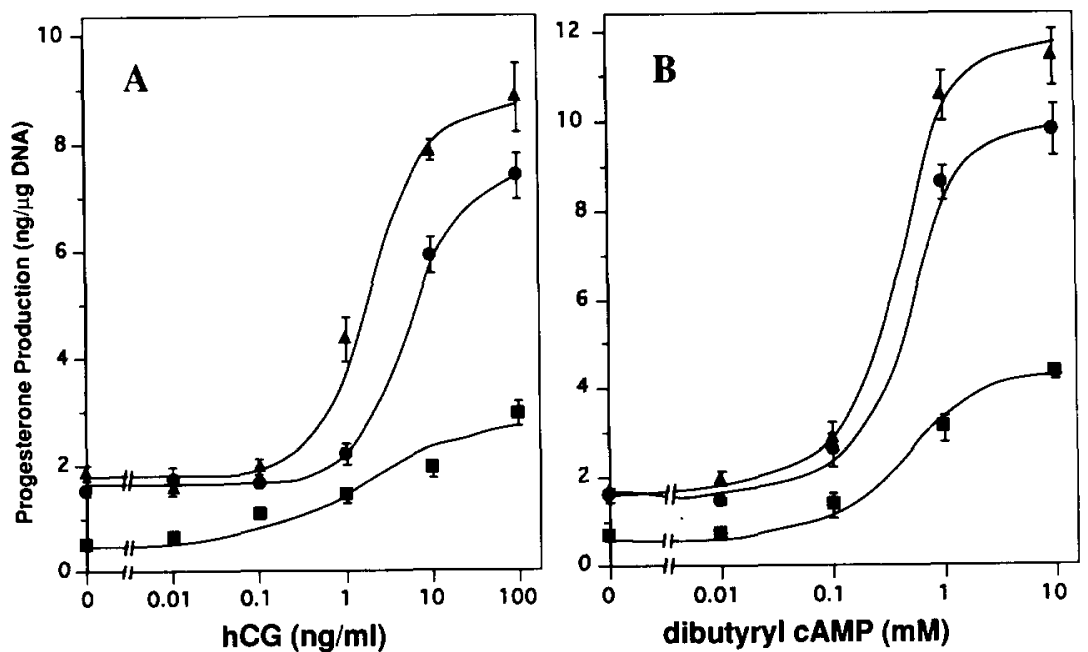

Fig. 3. Effects of acetyl-LDL (AcLDL) and native LDL (LDL) on progesterone secretion by dispersed rat luteal cells in response to increasing doses of hCG (panel A) or $\mathrm{Bt}_{2}$-cAMP (panel B). Rat luteal cells (approx. $2 \cdot 10^{6}$ ) were incubated at $37^{\circ} \mathrm{C}$ for $3 \mathrm{~h}$ with the indicated concentrations of $\mathrm{hCG}$ or $\mathrm{Bt}_{2}$-cAMP alone ( $\left.\square\right)$ and in the presence of AcLDL ( $\triangle$ ) or LDL $(\bullet)$ at the concentration of $200 \mu \mathrm{g}$ protein $/ \mathrm{ml}$. Values represent the means \pm S.E. of triplicate incubations at each concentration.

receptor and that two distinct pathways for native LDL and acetyl-LDL might exist in luteal cells. In contrast to the native LDL, both unlabeled acetyl-LDL and fucoidin effectively inhibited the cellular degradation of ${ }^{125} \mathrm{I}$-acetyl-LDL (by $75 \%$ and $90 \%$, respectively; Fig.7). Taken together, these data provide evidence for the existence of a scavenger receptor in this steroidogenic tissue.

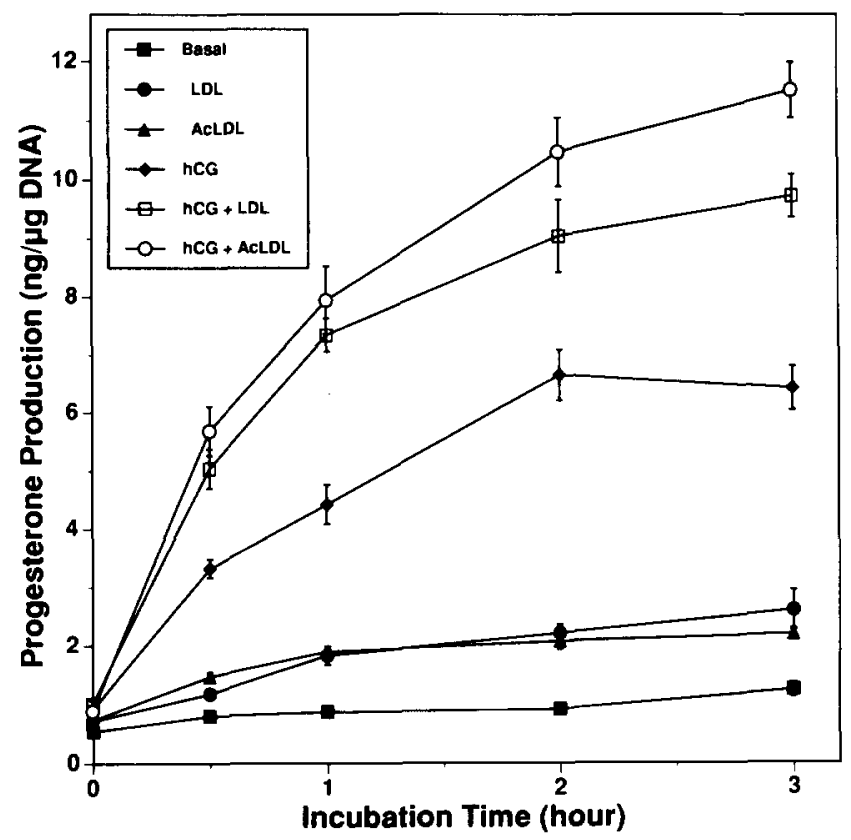

Fig. 4. Time-dependent effects of acetyl-LDL (AcLDL) and native LDL (LDL) and hCG on progesterone secretion by dispersed rat luteal cells. Aliquots of luteal cells (approx. $2 \cdot 10^{6}$ ) were incubated at $37^{\circ} \mathrm{C}$ alone and with AcLDL or LDL $(200 \mu \mathrm{g} / \mathrm{ml})$ in the absence or the presence of hCG $(100 \mathrm{ng} / \mathrm{ml})$. Values presented are the means \pm S.E. of triplicate incubations at each time point.
TNM-HDL as a ligand of scavenger receptor of luteal tissue

To examine the possibility whether nitrated HDL binds to a scavenger receptor in luteal cells, cross-competition between acetyl-LDL and TNM-HDL for bind-

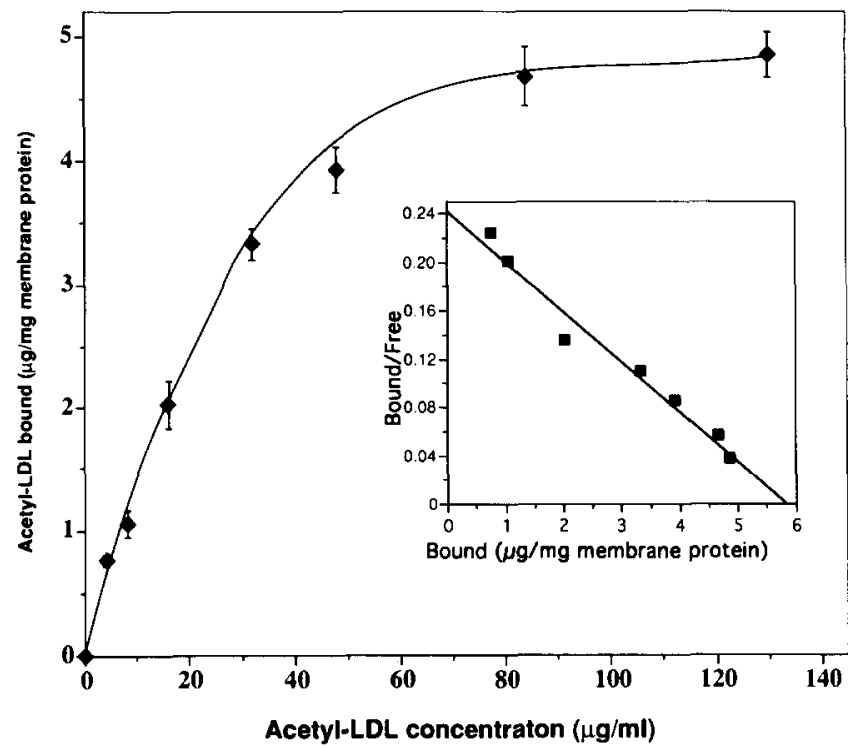

Fig. 5. Specific binding of acetyl-LDL (AcLDL) to rat ovarian plasma membrane preparations with increasing concentrations of AcLDL. Aliquots $(250 \mu \mathrm{g}$ protein) of membranes were incubated with a constant amount of ${ }^{125} \mathrm{I}$-AcLDL $\left(4 \mu \mathrm{g}{ }^{125} \mathrm{I}\right.$-AcLDL protein $/ \mathrm{ml}, 150$ $\mathrm{cpm} / \mathrm{ng}$ protein) with increasing amounts of unlabeled AcLDL in a total volume of $0.5 \mathrm{ml}$ of binding assay buffer at $37^{\circ} \mathrm{C}$ for $90 \mathrm{~min}$ (total binding). Nonspecific binding was determined in the presence of 200-fold excess of unlabeled AcLDL and subtracted from the total binding to obtain specific binding. The inset represents the transformation of binding data to Scatchard plot. All assays were carried out in four replicates. Values presented are the means $\pm S$.E. of four replicates. 
ing to luteinized ovarian plasma membranes was determined. Fig. 8 shows the competitive effects of several potential ligands on the binding of ${ }^{125}$ I-labeled TNMHDL to ovarian plasma membranes. Native LDL was entirely ineffective in displacing the ${ }^{125} \mathrm{I}$-TNM-HDL binding, while native HDL partially (by $25 \%$ ) competed for the binding. In contrast, unlabeled TNMHDL, acetyl-LDL and fucoidin significantly inhibited the binding (by 78\%). These data indicate that TNMHDL, acetyl-LDL and fucoidin bind to a common receptor. Furthermore, TNM-HDL displaced the binding of ${ }^{125}$ I-acetyl-LDL almost as effectively as unlabeled acetyl-LDL (Fig. 9), while native HDL had little effect. Thus, these data demonstrate that TNM-HDL is recognized as a ligand by a scavenger receptor of ovarian plasma membranes.

Regulation of luteal cell scavenger receptor by hCG administration

It is known that the expression of LDL receptor and HDL receptor of ovarian cells is regulated by luteinizing hormone or hCG $[4,30,31]$. Previous studies from our laboratory have shown that administration of hCG to pseudopregnant rats results in an increase in LDL and HDL receptor concentrations [4,30]. To examine the regulation of the luteal cell scavenger receptor, we

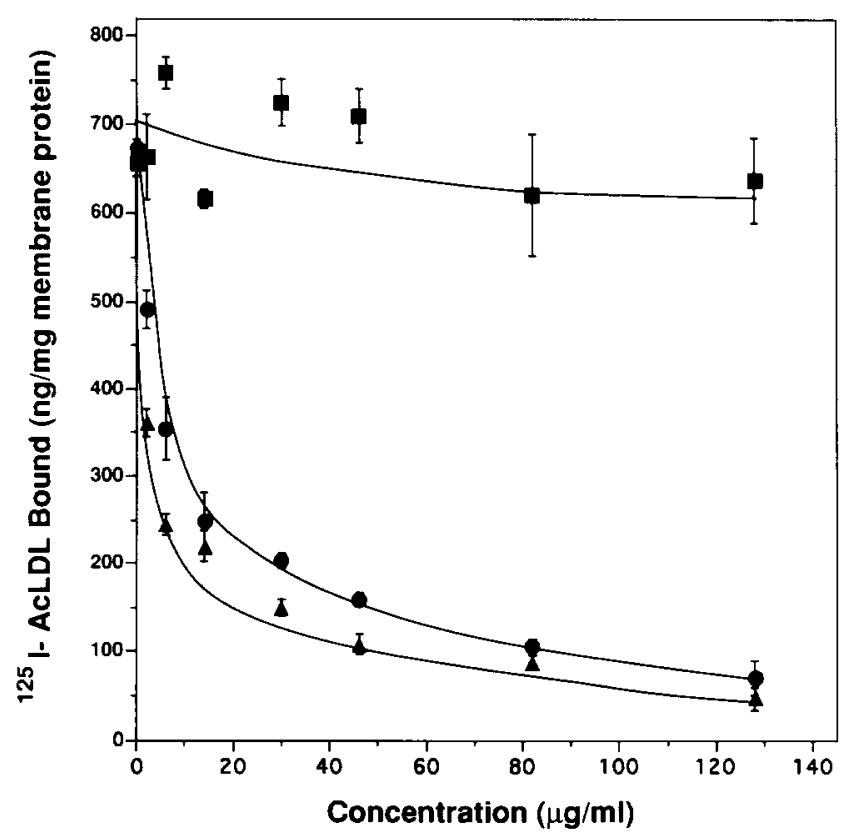

Fig. 6. Comparison of the ability of LDL, acetyl-LDL (AcLDL), or fucoidin to displace the binding of ${ }^{125}$ I-AcLDL to rat ovarian plasma membrane preparations. Aliquots $(250 \mu \mathrm{g}$ protein) of membranes were incubated at $37^{\circ} \mathrm{C}$ for $90 \mathrm{~min}$ in $0.5 \mathrm{ml}$ binding assay buffer containing ${ }^{125} \mathrm{I}-\operatorname{AcLDL}(5 \mu \mathrm{g} / \mathrm{ml}, 335 \mathrm{cpm} / \mathrm{ng}$ protein $)$ alone or with varying concentrations of either LDL ( $\bullet)$, AcLDL ( $\bullet$, or fucoidin $(\star)$. The binding to membranes in the presence a 200 -fold excess of unlabeled AcLDL (nonspecific binding) was subtracted at each data point. Values presented are the means \pm S.E. of triplicate incubations.

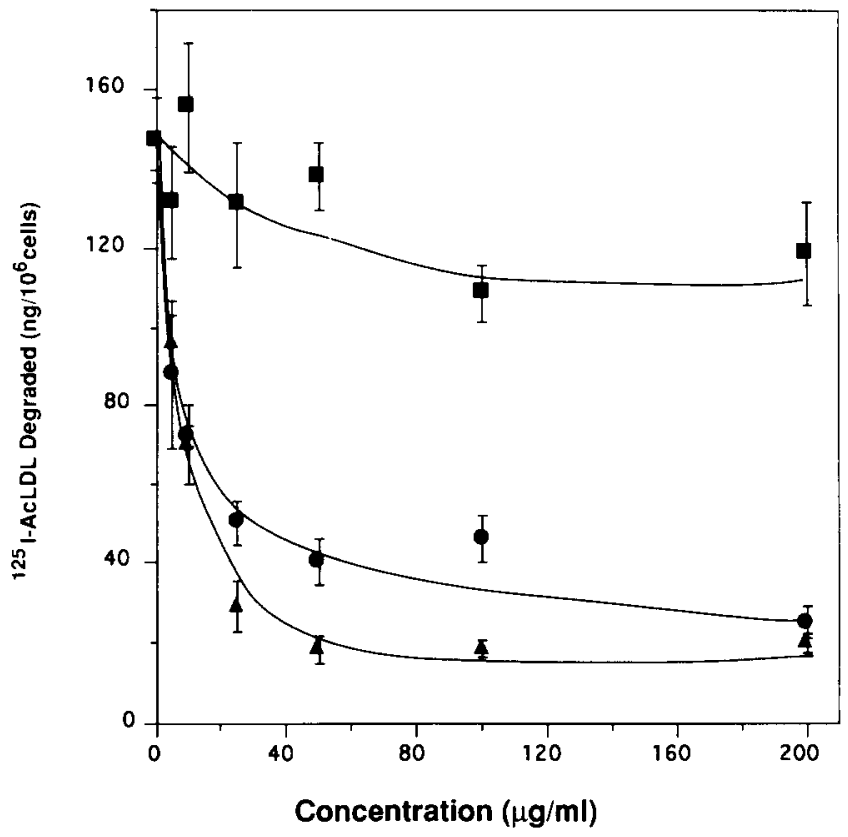

Fig. 7. Comparison of the ability of LDL, acetyl-LDL (AcLDL), or fucoidin to inhibit degradation of ${ }^{125}$ I-AcLDL by cultured rat luteal cells. Cultured rat luteal cells were incubated with ${ }^{125} \mathrm{I}$-AcLDL $(6$ $\mu \mathrm{g} / \mathrm{ml}, 135 \mathrm{cpm} / \mathrm{ng}$ protein) alone and in the presence of increasing concentrations of $\operatorname{LDL}(\boldsymbol{\bullet})$, AcLDL $(\bullet)$, or fucoidin $(\Delta)$ at $37^{\circ} \mathrm{C}$ for $6 \mathrm{~h}$. The media were collected and the proteins precipitated with $10 \%$ trichloroacetic acid. The radioactivity in the supernatant was determined to estimate the degradation of ${ }^{125} \mathrm{I}$-AcLDL as described in Experimental procedures. Degradation in wells containing a 200 fold excess of unlabeled AcLDL (nonspecific degradation) was subtracted at each data point. Values presented are the means \pm S.E. of five wells.

determined the effect of hCG administration on acetylLDL binding to ovarian plasma membranes. As shown in Table 1 , administration of hCG caused a significant increase in ${ }^{125} \mathrm{I}$-acetyl-LDL binding at $12 \mathrm{~h}$ and $24 \mathrm{~h}$ following treatment (by $68 \%$ and $85 \%$, at $12 \mathrm{~h}$ and 24 $\mathrm{h}$, respectively, $P<0.01$ ) and this increase diminished by $60 \mathrm{~h}$. The binding activity of ${ }^{125} \mathrm{I}$-acetyl-LDL was almost constant in the control rats injected with saline during the entire time course (Table I). These data, therefore, suggest that scavenger receptor of luteal cells is metabolically regulated by hCG, a hormone that stimulates progesterone production in the ovary.

In order to determine whether the increase in ${ }^{125} \mathrm{I}$ acetyl-LDL binding activity by hCG administration was caused by an increase in the number of binding sites or by a change in binding affinity, experiments were carried out to determine the affinity and the receptor concentration in the control and hCG-treated groups. The binding activities of acetyl-LDL in both the control and the hCG-treated groups as a function of acetyl-LDL concentration were transformed into Scatchard plots (Fig. 10) [29]. The binding capacity, $B_{\max }$, in the hCG-treated group was 1.9-fold greater than that seen in control group (13.5 vs. $7.2 \mu \mathrm{g}$ acetyl- 


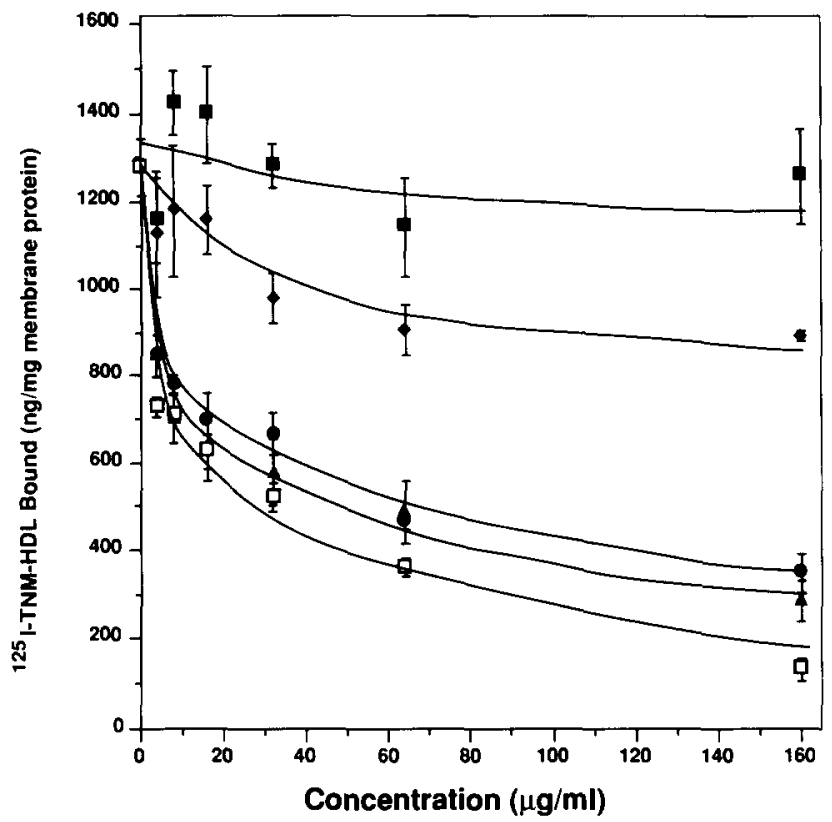

Fig. 8. Effects of LDL, HDL, fucoidin, acetyl-LDL (AcLDL) and TNM-HDL on the binding of ${ }^{125}$ I-TNM-HDL to rat ovarian plasma membrane preparations. Aliquots $(250 \mu \mathrm{g}$ protein) of membranes were incubated with ${ }^{125} \mathrm{I}$-TNM-HDL $(4 \mu \mathrm{g} / \mathrm{ml}, 620 \mathrm{cpm} / \mathrm{ng}$ protein) alone and with increasing concentrations of LDL ( $\bullet)$, HDL ( $\bullet$, fucoidin ( $₫$ ), AcLDL $(\bullet)$ or unlabeled TNM-HDL $(\square)$ at $37^{\circ} \mathrm{C}$ for $90 \mathrm{~min}$ in $0.5 \mathrm{ml}$ of binding assay buffer. The binding to membranes in the presence of 200-fold excess of unlabeled TNM-HDL (nonspecific binding) was subtracted at each data point. Values are the means \pm S.E. of triplicates.

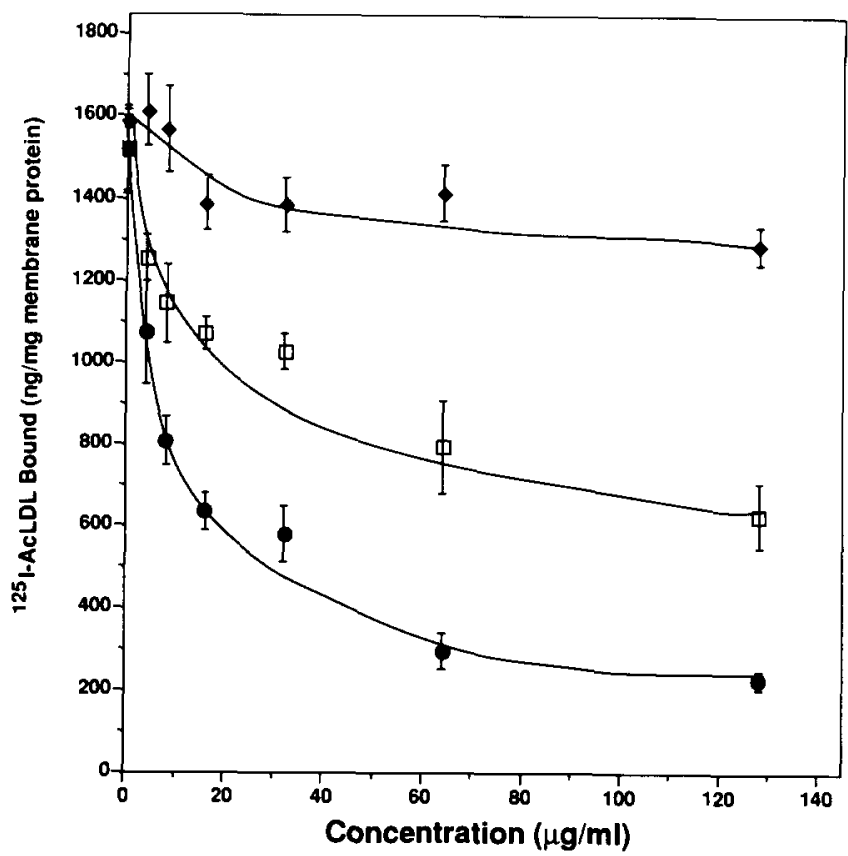

Fig. 9. Comparison of the ability of HDL, TNM-HDL and acetyl-LDL (AcLDL) to compete with the binding of ${ }^{125}$ I-AcLDL to rat ovarian plasma membrane preparations. Aliquots ( $250 \mu \mathrm{g}$ protein) of membranes were incubated with ${ }^{125} \mathrm{I}$-AcLDL $(7 \mu \mathrm{g} / \mathrm{ml}, 150 \mathrm{cpm} / \mathrm{ng}$ protein) alone and with increasing concentrations of HDL ( $\downarrow)$, TNM-HDL ( $\square$ ) or AcLDL ( $\bullet$ ) at $37^{\circ} \mathrm{C}$ for $90 \mathrm{~min}$ in $0.5 \mathrm{ml}$ binding assay buffer. Nonspecific binding was subtracted at each data point.

Values presented are the means \pm S.E. of triplicates.
TABLE I

Time-course effect of hCG injection on ${ }^{125} I$-acetyl-LDL binding to rat ovarian plasma membrane preparations

Ovaries were isolated from pseudopregnant rats at different periods following subcutaneous injection with hCG or saline. Aliquots (250 $\mu \mathrm{g}$ protein) of membranes were incubated with ${ }^{125} \mathrm{I}$-AcLDL (5 $\mu \mathrm{g} / \mathrm{ml}, 210 \mathrm{cpm} / \mathrm{ng}$ protein) in a total volume of $0.5 \mathrm{ml}$ binding assay buffer either alone (total binding) or together with a 200 -fold excess of unlabeled AcLDL (nonspecific binding) at $37^{\circ} \mathrm{C}$ for $90 \mathrm{~min}$. The specific binding was calculated by subtracting the nonspecific binding from the total binding. Values presented are means \pm S.E. $(n=3)$. ${ }^{*} P<0.05 ; * * P<0.01$ significantly different from the corresponding values from rats injected with saline.

\begin{tabular}{lll}
\hline $\begin{array}{l}\text { Time post } \\
\text { injection }(\mathrm{h})\end{array}$ & \multicolumn{2}{l}{$\begin{array}{l}\text { AcLDL bound } \\
(\mu \mathrm{g} / \mathrm{mg} \text { membrane protein })\end{array}$} \\
\cline { 2 - 3 } & saline & hCG $(25 \mathrm{IU})$ \\
\hline 0 & $1.339 \pm 0.140$ & $1.479 \pm 0.161$ \\
12 & $1.386 \pm 0.101$ & $2.334 \pm 0.099 *$ \\
24 & $1.194 \pm 0.114$ & $2.237 \pm 0.085 * *$ \\
60 & $1.047 \pm 0.080$ & $1.365 \pm 0.113 *$ \\
\hline
\end{tabular}

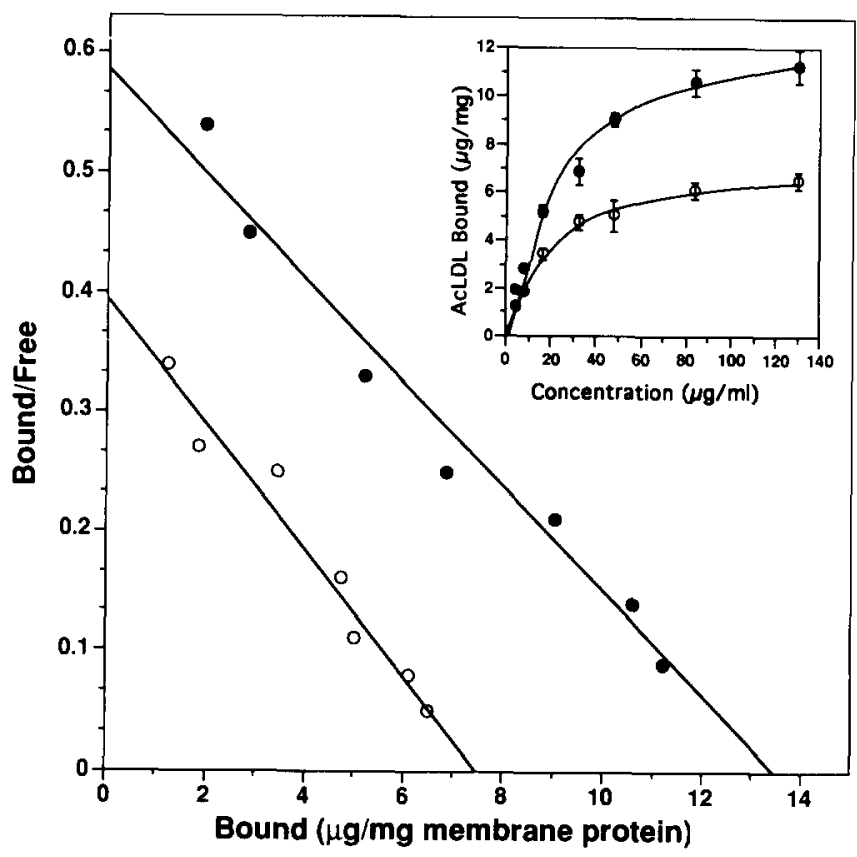

Fig. 10. Effects of hCG injection on acetyl-LDL (AcLDL) binding to rat ovarian plasma membrane preparations depicted as Scatchard plots. Ovaries were isolated from pseudopregnant rats $24 \mathrm{~h}$ after subcutaneous injection with $25 \mathrm{IU}$ hCG or saline. Aliquots $(250 \mu \mathrm{g}$ protein) of ovarian plasma membranes were incubated with a constant amount of ${ }^{125} \mathrm{I}$-AcLDL $\left(4 \mu \mathrm{g}{ }^{125} \mathrm{I}\right.$-AcLDL protein $/ \mathrm{ml}, 140$ $\mathrm{cpm} / \mathrm{ng}$ protein) with increasing amounts of unlabeled AcLDL in a total volume of $0.5 \mathrm{ml}$ of binding assay buffer at $37^{\circ} \mathrm{C}$ for $90 \mathrm{~min}$ (total binding). Nonspecific binding was determined in the presence of 200 -fold excess of unlabeled AcLDL and subtracted from the total binding to obtain specific binding. The inset shows the specific binding as a function of AcLDL concentration. All assays were carried out in four replicates ( $O$, control group; $\bullet$, hCG-treated group). 
$\mathrm{LDL} / \mathrm{mg}$ membrane protein), while the $K_{\mathrm{d}}$ values for both control and hCG-treated groups were similar (22.5 vs. $19.2 \mu \mathrm{g} / \mathrm{ml}$ ). Thus, the increase in scavenger receptor activity seen after hCG administration was caused by an increase in the number of binding sites rather than by a change in the binding affinity.

\section{Discussion}

The present study demonstrates that, in addition to the previously characterized receptor-mediated LDL and HDL pathways, rat luteal cells also possess a scavenger receptor pathway which recognizes TNMmodified HDL as well as acetyl-LDL. Furthermore, the scavenger receptor is up-regulated by hCG in vivo.

The presence of scavenger receptor was demonstrated in two different ways. First, we found that acetyl-LDL supports progesterone production by rat luteal cells to a degree at least equal to that of native LDL. It is already known that acetylation of LDL abolishes its ability to bind to LDL receptor and thus renders it incapable to deliver its sterols $[10,32]$. The cellular accumulation of cholesterol from acetyl-LDL requires a scavenger receptor pathway $[10,11]$. Our present observation that acetyl-LDL supports progesterone production strongly suggests that a scavenger receptor pathway is operational in rat luteal cells. Second, the interaction of acetyl-LDL with the ovarian plasma membranes showed a single class of binding sites with high affinity and saturability. The binding affinity is comparable to that of the macrophage scavenger receptor [10,33]. Both unlabeled acetyl-LDL and fucoidin, a known competitor for binding to the scavenger receptor [10], but not native LDL, displaced the binding of ${ }^{125} \mathrm{I}$-acetyl-LDL, indicating that the binding site is specific for acetyl-LDL and related ligands. The fact that the ligand binding activity of the scavenger receptor is induced by hCG signifies that this receptor might be physiologically regulated. Furthermore, by using luteal cell culture, we found that the degradation of ${ }^{125}$ I-acetyl-LDL was effectively inhibited both by unlabeled acetyl-LDL and by fucoidin, but not by native LDL. These experiments provide strong evidence for the existence of a functional scavenger receptor pathway in a cell type that largely depends on exogenous sterol as a precursor for steroidogenesis.

A novel characteristic of the scavenger receptor is its binding specificity for a broad, but limited set of ligands [10,11]. Thus, scavenger receptor in macrophages and endothelial cells recognizes not only acetylLDL [11] but also modified HDL [9,34]. Previous studies have shown that TNM-modified HDL is recognized by the scavenger receptor [9]. Similarly, modification of HDL with a chemical cross-linker, dithiobis(succinimidyl) propionate (DSP), has also been reported to result in a significant loss of its ability to bind to the
HDL receptor and thereby generating a new ligand for the scavenger receptor [34]. The enhanced negative charges in TNM-HDL, DSP-modified HDL and acetylLDL might be a common denominator that renders them able to bind to the scavenger receptor. The modified HDL particles, like other ligands for the scavenger receptor, are internalized following its binding to the receptor $[9,34]$. In the present study, we also found that TNM-HDL is recognized by a scavenger receptor, suggesting similarity in the ligand specificity between scavenger receptor of luteal cells and that of other cell types. Recently, Krieger and colleagues [3537] have purified and cloned two forms of the scavenger receptor from bovine lung, and the amino acid sequences have been deduced from the cDNAs. This receptor is a $220 \mathrm{kDa}$ protein which is a trimer of 77 $\mathrm{kDa}$ subunits [36]. The two forms of scavenger receptor differ only by the presence in one form of an extracellular cysteine-rich C-terminal domain [37]. When expressed in COS cells either transiently $[36,37]$ or stably [38], both forms of the receptors were shown to mediate the endocytosis of acetyl-LDL with essentially the same affinity and the same distinctive broad ligand binding specificity. The similarity in the structures of these receptors suggests that they may exit as mixed trimers [36,38]. A high molecular mass $(260 \mathrm{kDa})$ scavenger receptor has also been purified from a murine macrophage cell line [33]. It is not known whether the scavenger receptor reported here belongs to Type I, Type II, or a new scavenger receptor family. In fact, a recent study has suggested that different tissues may possess different scavenger receptors yet they share similar ligand binding specificities [39].

Although more detailed information on the structure of scavenger receptor of ovarian cells remains to be established, the demonstration of the ability of acetyl-LDL to support luteal cell progesterone production in conjunction with the finding that this receptor is up-regulated by hCG in vivo suggests that this receptor might play a role in steroidogenesis by the ovary. In fact, Alsat et al. [40,41] have recently described a scavenger receptor in microvillous membranes from human placenta and the uptake and endocytosis of acetyl-LDL particles by human syncytiotrophoblastic cells, suggesting that a scavenger receptor is also present in the steroidogenic cells of human placenta. However, the functional role for that receptor in steroidogenesis is not known. Although acetyl-LDL is metabolized through a pathway which is different from that of the native LDL [10,11], both acetyl-LDL and native LDL undergo lysosomal degradation, leading to the release of cholesterol. We now provide evidence that, as in the LDL receptor pathway, the cholesterol delivered by the scavenger receptor pathway can also be utilized for steroidogenesis.

The physiological ligand for this receptor is yet to be 
understood, because acetylation of LDL is thought not to occur in vivo [11]. In other cell types, such as macrophages, scavenger receptor mediates substantial intracellular cholesteryl ester accumulation which leads to the formation of 'foam cells' [10,11]. Modifications (e.g., oxidative modification) of lipoprotein particles, which allow the modified LDL particles to serve as ligands for the scavenger receptor, have been shown to occur when native LDL is incubated in vitro with endothelial cells [42] and also in vivo in human aortic cells [43]. Whether LDL also undergoes such modifications in the ovarian cells is not yet known. Recent studies have shown that superoxide [44] and hydrogen peroxide [45] are generated in regressing rat corpora lutea. Lipid peroxidation has also been shown to occur during corpus luteum demise [46]. The presence of these free radicals is believed to be the key element of cell-induced oxidative modification of LDL [47]. Thus, modifications of LDL might occur in vivo in regressing rat corpus luteum. The presence of scavenger receptor in steroidogenic cells might therefore serve as a mechanism to metabolize the oxidatively damaged LDL particles.

While the physiological ligands of scavenger receptor of luteal cells remain to be established, the presence of the scavenger receptor pathway in luteal cells strongly suggests that TNM-modified HDL delivers its cholesterol for steroidogenesis through this pathway and this does not involve HDL receptor. Thus, the previous observation that TNM-modified HDL does not bind to HDL receptor but is still able to support steroidogenesis by ovarian cells, as described by Nestler et al. [7], does not necessarily support a non-receptor mediated uptake of HDL cholesterol for steroidogenesis.

In conclusion, the present study demonstrates that, in addition to receptor-mediated LDL and HDL pathways, rat luteal cells possess a scavenger receptor pathway. The scavenger receptor in luteal cells recognizes nitrated HDL as well as acetyl-LDL and it is upregulated by hCG in vivo. This receptor might function to mediate the uptake and utilization of modified lipoprotein-associated cholesterol for steroidogenesis by the luteal cells. The physiological ligands for the receptor are yet to be determined.

\section{Acknowledgement}

This study was supported by NIH grant HD 06656 .

\section{References}

1 Azhar, S. and Menon, K.M.J. (1981) Biochim. Biophys. Acta 665, 362-375.

2 Gwynne, J.T. and Strauss, J.F., III (1982) Endocrine Rev. 3, 299-329.
3 Paavola, L.G., Strauss, J.F., III, Boyd, C.O. and Nestler, J.E. (1985) J. Cell Biol. 100, 1235-1247.

4 Hwang, J. and Menon, K.M.J. (1983) J. Biol. Chem. 258, 80208027.

5 Rajan, V.P. and Menon, K.M.J. (1987) Biochim. Biopyhs. Acta 921, 25-37.

6 Chacko, G.K. (1985) J. Lipid Res. 26, 745-754.

7 Nestler, J.E., Chacko, G.K. and Strauss, J.F., III (1985) J. Biol. Chem. 260, 7316-7321.

8 Nestler, J.E., Takagi, K. and Strauss, J.F., III (1990) Advances in Cholesterol Research (Esfahani, M. and Swaney, J.B., eds.), pp. 133-169, Telford Press, Caldwell, NJ.

9 Kleinherenbrink-Stins, M.F., Schouten, D., Van der Boom, J., Brouwer, A., Knook, D.L. and Van Berkel, T.J.C. (1989) J. Lipid Res. 30, 511-520.

10 Goldstein, J.L., Ho, Y.K., Basu, S.K. and Brown, M.S. (1979) Proc. Natl. Acad. Sci. USA 76, 333-337.

11 Brown, M.S. and Goldstein, J.L. (1983) Annu. Rev. Biochem. 52, 233-261.

12 Pitas, R.E., Boyles, J., Mahley, R.W. and Bissell, D.M. (1985) J. Cell Biol. 100, 103-117.

13 Pitas, R.E. (1990) J. Biol. Chem. 265, 12722-12727.

14 Havel, R.J., Eder, H.A. and Bragdon, J.H. (1955) J. Clin. Invest. 34, 1345-1353.

15 Weisgraber, K.H. and Mahley, R.W. (1980) J. Lipid Res. 21, 316-325.

16 Laemmli, U.K. (1970) Nature 227, 680-685.

17 Basu, S.K., Goldstein, J.L., Anderson R.G.W. and Brown, M.S. (1976) Proc. Natl. Acad. Sci. USA 73, 3178-3182.

18 Noble, R.P. (1968) J. Lipid Res. 9, 693-700.

19 MacFarlan, A.S. (1958) Nature 182, 53.

20 Parlow, A.F. (1958) Fed. Proc. 17, 402.

21 Menon, M., Peegel, H. and Menon, K.M.J. (1985) J. Steroid Biochem. 22, 79-84.

22 Burton, K. (1956) Biochem. J. 62, 315-322.

23 Rajendran, K.G., Hwang, J. and Menon, K.M.J. (1983) Endocrinology $112,1746-1753$.

24 Bierman, E.L., Stein, O. and Stein, Y. (1974) Circ. Res. 35, $136-150$.

25 Powell, W.S., Hammerstrom, S. and Samuelsson, B. (1976) Eur. J. Biochem. 61, 605-611.

26 Ferreri. K. and Menon, K.M.J. (1992) Biochem. J. 287, 841-848.

27 Morre, O.J. (1971) Methods Enzymol. 22, 130-148.

28 Deacon, A.C. and Dawson, P.J.G. (1979) Clin. Chem. 25, 976-984.

29 Scatchard, G. (1949) Ann. N.Y. Acad. Sci. 51, 660-672.

30 Ghosh, D.K. and Menon, K.M.J. (1987) Biochem. J. 244, 471-479.

31 Golos, T.G. and Strauss, J.F. (1985) J. Biol. Chem. 260, 1439914402.

32 Mahley, R.W., Innerarity, T.L., Pitas, R.E., Weisgraber, K.H., Brown, J.H. and Gross, E. (1977) J. Biol. Chem. 252, 7279-7287.

33 Via, D.P., Dresel, H.A., Cheng, S.L. and Gotto, A.M., Jr. (1985) J. Biol. Chem. 260, 7379-7386.

34 Miyazaki, A., Rahim, A.T.M.A., Araki, S., Morino, Y. and Horiuchi, S. (1991) Biochim. Biophys. Acta 1082, 143-151.

35 Kodama, T., Reddy, P., Kishimoto, C. and Krieger, M. (1988) Proc. Natl. Acad. Sci. USA 85, 9238-9242.

36 Kodama, T., Freeman, M., Rohrer, L., Zabrechy, J., Matsudaira, P. and Krieger, M. (1990) Nature 343, 531-535.

37 Rohrer, L., Freeman, M., Kodama, T., Penman, M. and Krieger, M. (1990) Nature 343, 570-572.

38 Freeman, M., Ekkel, Y., Rohrer, L., Penman, M., Freedman, N.J., Chilsolm, G.M. and Krieger, M. (1991) Proc. Natl. Acad. Sci. USA 88, 4931-4935.

39 Bickel, P.E. and Freeman, M.W. (1992) J. Clin. Invest. 90:14501457.

40 Alsat, E., Mondon, F., Rebourcet, R., Berthelier, M., Erlich, D., 
Cedard, L. and Golstein, S. (1985) Mol. Cell. Endocrinol. 41, 229-235.

41 Malassine, A., Alsat, E., Besse, C., Rebourcet, R. and Cedard, L. (1990) Placenta 11, 191-204.

42 Henriksen, T., Mahoney, E.M. and Steinberg, D. (1981) Proc. Natl. Acad. Sci. USA 78, 6499-6503.

43 Clevidence, B.A., Morton, R.E., West, G., Dusek, D.M. and Hoff, H.F. (1984) Arteriosclerosis 4, 196-207.
44 Swada, M. and Carlson, J.C. (1989) Can. J. Physiol. Pharmacol. $67,465-471$.

45 Riley, J.C.M. and Behrman, H.R. (1991) Endocrinology 128, 1749-1753.

46 Greenhalgh, E.A. (1990) J. Endocrinol. 125, 397-402.

47 Steinberg, D., Parthasarathy, S., Carew, T.E., Khoo, J.C. and Witztum, J.L. (1989) New Engl. J. Med. 320, 1915-1924. 